WHC-SP-0918

Rev. 0

UC- 600

\title{
Maintenance Implementation Plan for the Grout Facility
}

\author{
A. K. Yoakum \\ Date Publishad \\ August 1993
}

Prepared for the U.S. Department of Energy Office of Environmental Restoration and Waste Management

\footnotetext{
(2) Westinghouse Hanford Company Richland, Washington 9935 a

Hantord Operations and Engineering Contractor for the

U.S. Department of Energy under Contract DE-AC06-87RL10930
}

Approved for Public Release 


\section{LEGAL DISCLAMER}

This report was prepared as an account of work sponsored by an agency of the United States Government. Neither the United States Government nor any agency thereof, nor any of their employees, nor any of their contractors, subcontractors or their employees, makes any warranty, express or implied. or assumes any legal liability or responsibility for the accuracy, completeness, or any third party's use or the results of such use of any information, apparatus, product, or process disclosed. or represents that its use would not intringe privately owned rights. Reference herein to any specific commercial product, process, or service by trade name. trademark, manufacturer, or otherwise, does not necessarily constitute or imply its endorsement, recommendation, or favoring by the United States Government or any agency thereot or its contractors or subcontractors. The views and opinions of authors expressed herein do not necessarily state or reflect those of the United States Government or any agency thereot

This report has been reproduced from the best availabie copy Available in paper copy and microfiche.

Available to the U.S. Department of Energy and its contractors from

Otfice of Scientific and Technical Intormation P. 0. Box 62

Oak Ridge. TN 37831

(615) 576-840

Printed in the Unitod Stater of Amorica 
WHC-SP-0918, REV. 0

APPROVAL PAGE

DOCUMENT TITLE: MAINTENANCE IMPLEMENTATION PLAN FOR THE GROUT FACILITY

Prepared by:

Approved by:

Approved by:

$$
\frac{7-16-93}{\text { Date }}
$$

Grout/Maintenance
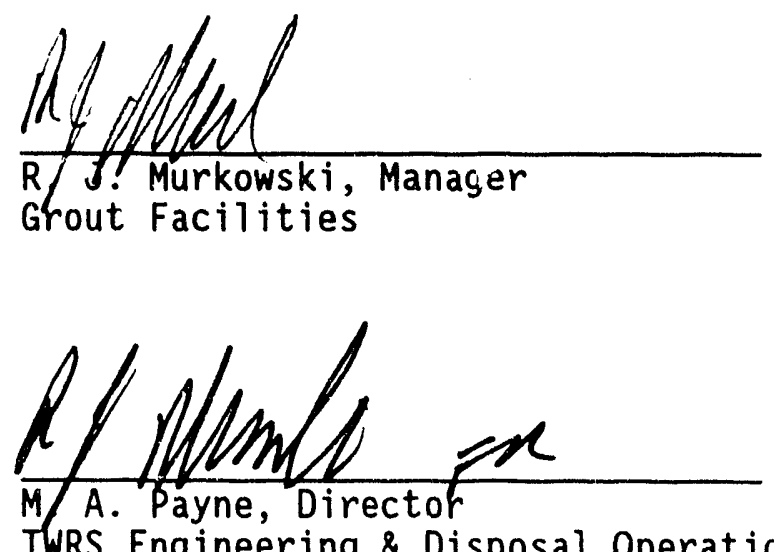

TWRS Engineering \& Disposal Operations

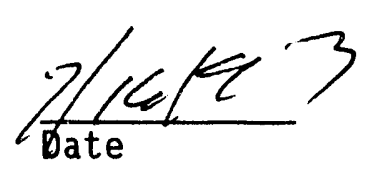

$\frac{7-26-93}{\text { Date }}$ 


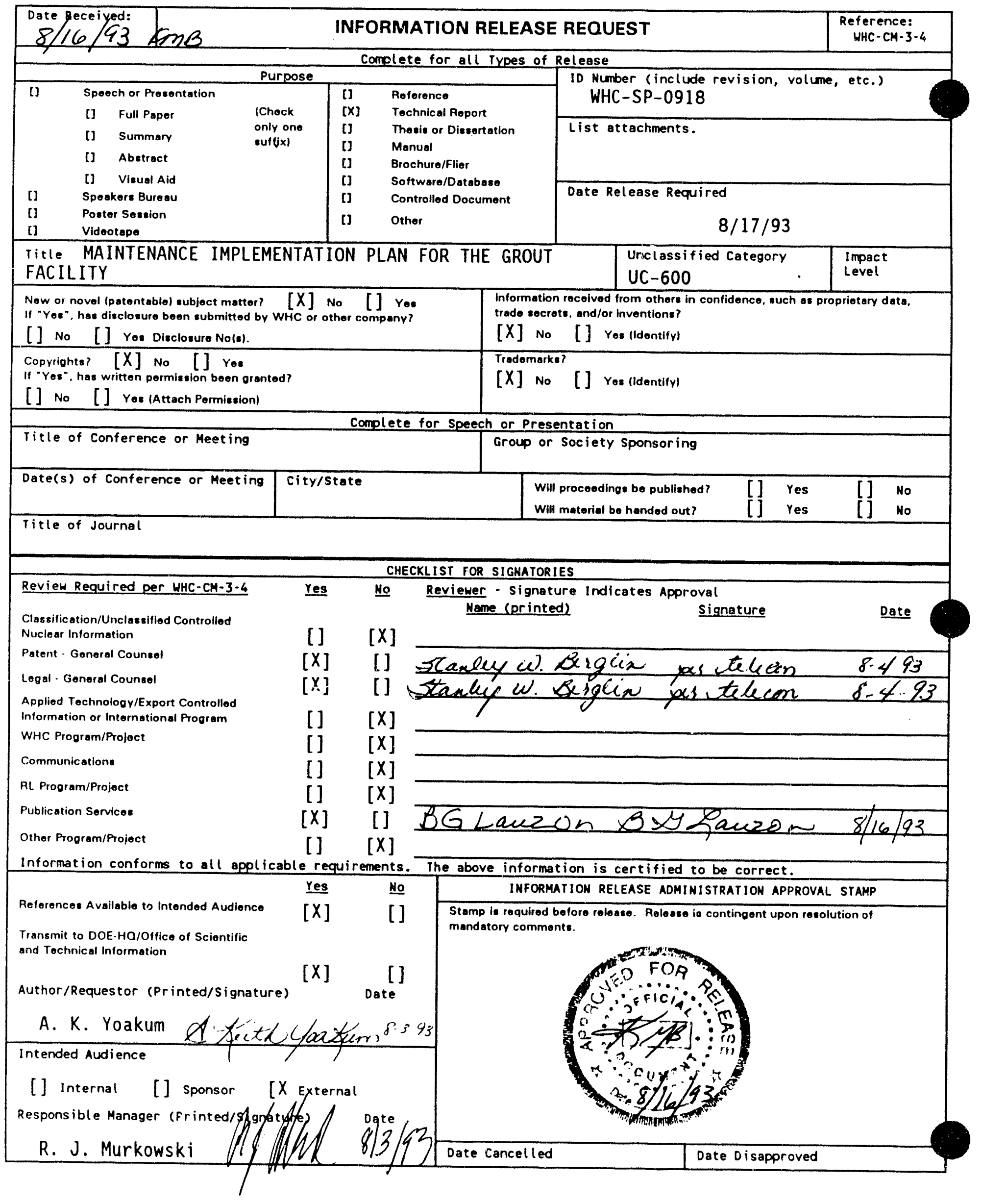


WHC-SP-0918, Rev. 0

CONTENTS

1.0 EXECUTIVE SUMMARY . . . . . . . . . . . . . . . 1-1

2.0 INTRODUCTION . . . . . . . . . . . . . . . . . . 2-1

2.1 FACILITY DESCRIPTION . . . . . . . . . . . . . . . 2-1

2.2 MISSION .................... 2-2

2.3 HISTORY/SCHEDULED LIFE . . . . . . . . . . . . . . . 2-2

3.0 DOE 4330.4A REQUIREMENTS IN ADDITION TO

THOSE STATED IN CHAPTER II . . . . . . . . . . . . . . . 3-1

3.1 IDENTIFICATION OF STRUCTURES, SYSTEMS, AND COMPONENTS
INCLUDED WITHIN THE MAINTENANCE PROGRAM ... 3-1

3.2 SYSTEMATIC ANALYSIS DESCRIBING SYSTEM/COMPONENTS

INCLUDED WITHIN THE PREVENTIVE MAINTENANCE

PROGRAM, AND DETERMINATION OF FREQUENCY OF

MAINTENANCE ACTIONS . . . . . . . . . . . . . . . . . 3-1

3.3 MAINTENANCE SELF-ASSESSMENTS . . . . . . . . . . . . . . . . 3-1

3.4 GRADED APPROACH TO MAINTENANCE . . . . . . . . . . . . . . . . 3-2

4.0 DOE ORDER 4330.4A CHAPTER II REQUIREMENTS ............. . 4-1

4.1 MAINTENANCE ORGANIZATION AND ADMINISTRATION . . . . . . . . . . 4-1

4.1.1 Maintenance Organization Policies..... . . . . . . 4-1

4.1.2 Maintenance Sirategy .. . . . . . . . . . . . . 4-2

4.1.3 Staffing Resources ................ . 4-2

4.1.4 Goals and Objectives . . . . . . . . . . . . . 4-2

4.1.5 Accountability . . . . . . . . . . . . . . . 4-3

4.2 TRAINING AND QUALIFICATION UF MAINTENANCE PERSONNEL . . . . . . 4-3

4.2.1 Responsibilities . . . . . . . . . . . . . . . . 4-4

4.2.2 Maintenance Training Programs . . . . . . . . . . . . . 4-4

4.2.3 Training Schedules and Support . . . . . . . . . . . 4-4

4.2.4 On-the-Job Training ................ 4-5

4.2.5 Qualification ................. 4-5

4.2.6 Training in Root Cause Analysis . . . . . . . . . . . . 4-6

4.2.7 Training Program Approval, Effectiveness and Feedback . 4-6

4.2.8 Management and Supervisory Training . . . . . . . . 4-6

4.3 MAINTENANCE FACILITIES, EQUIPMENT AND TOOLS . . . . . . . . . . . $4-7$

4.4 TYPES OF MAINTENANCE ...................... . . . $4-7$

4.5 MAINTENANCE PROCEDURES . . . . . . . . . . . . . . . . . 4-8

4.5.1 Procedure Development and Writing . . . . . . . . . . . 4-8

4.5.2 Procedure Verification ... . . . . . . . . . . . 4 4-9

4.5.3 Procedure Validation ................ . 4-9

4.5.4 Procedure Approval .. . . . . . . . . . . . . . . . . 4-9

4.5.5 Procedure Use . . . . . . . . . . . . . . . . . . . 4-10

4.5.6 Procedure Control, Periodic Review and Revision . . . 4-10

4.6 PLANNING, SCHEDULING AND COORDINATION OF MAINTENANCE . . . . . 4-11

4.6.1 Planning for Maintenance Activities . . . . . . . . . . 4-11

4.6.2 Schedul ing Maintenance Activities . . . . . . . . . . "4-11

4.6.3 Coordination of Maintenance Activities . . . . . . . 4-12

4.6.4 Outage Planning, Scheduling and Coordination . . . . 4-12 
CONTENTS (Continued)

4.7 CONTROL OF MAINTENANCE ACTIVITIES . . . . . . . . . . 4-12

4.7.1 Work Control Procedure .. . . . . . . . . . . . . . 4-13

4.7.2 Work Request . . . . . . . . . . . . . . . . . . 4-13

4.7.3 Supervisor of Maintenance Activities . . . . . . . . . 4-13

4.7.4 Review of Completed Work Requests......... . . . 4-14

4.7.5 Temporary Repairs... . . . . . . . . . . . . . . 4-14

4.7.6 Control of Nonnuclear Facility Contractor and

Subcontractor Personnel ............ 4-14

4.8 POST-MAINTENANCE TESTING . . . . . . . . . . . . . . . . . . . . 4-15

4.8.1 Post-maintenance Test Requirements . . . . . . . . . . 4-15

4.8.2 Post-maintenance Test Scope ............. . 4-15

4.8.3 Post-maintenance Test Control ......... . . 4-16

4.8.4 Post-maintenance Test Performance, Documentation, and Acceptance . . . . . . . . . . . . . 4-16

4.9 PROCUREMENT OF PARTS, MATERIALS, AND SERVICES . . . . . . . . 4-17

4.10 MATERIAL RECEIPT, INSPECTION, HANDLING, STORAGE

4.10.1 Receipt Inspection ............... . . . . . . . .

4.10.2 Handling ................... . 4-18

4.10.3 Storage Material and Equipment . . . . . . . . . . 4-18

4.10.4 Retrieval and Issuance . . . . . . . . . . . 4-18

4.11 CONTROL AND CALIBRATION OF MEASURING AND TEST EQUIPMENT . . 4-19

4.11.1 Identification ................ 4-19

4.11.2 Calibration .................... 4-19

4.11.3 Control..................... . . 4-20

4.11.4 Evaluation .................... . . . . . . . 20

4.12 MAINTENANCE TOOLS AND EQUIPMENT . . . . . . . . . . . . . . . 4-21

4.13 FACILITY CONDITION INSPECTION . . . . . . . . . . . . . . . . 4-21

4.14 MANAGEMENT INVOLVEMENT . . . . . . . . . . . . . . . . . . . 4-22

4.14.1 Manager Involvement . . . . . . . . . . . . . . . . 4-22

4.14.2 Performance Indicators, Goals, and Objectives... . 4-23

4.14.3 Feedback . . . . . . . . . . . . . . . . . . 4-23

4.14.4 Program Reviews .. . . . . . . . . . . . . . . . 4-24

4.15 MAINTENANCE HISTORY . . . . . . . . . . . . . . . . . . . . . . . . . 4-24

4.16 ANALYSIS OF MAINTENANCE PROBLEMS . . . . . . . . . . . . . . . . . . 4-25

4.17 MODIFICATION WORK . . . . . . . . . . . . . . . . . . . . 4-25

4.18 SEASONAL FACILITY PRESERVATION REQUIREMENTS . . . . . . . 4-26

4.18.1 Cold Weather/Freeze Protection Plan . . . . . . . . . . 4-26

4.18.2 Actions Required ................ . . 4-26

4.18.3 Surveillance ................... . . 4-27

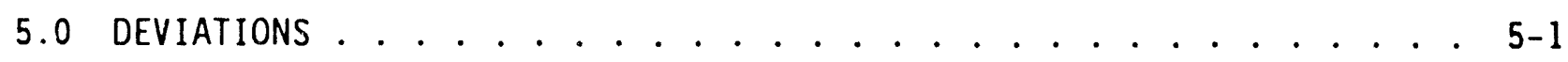

6.0 IMPLEMENTATION SCHEDLLE ...................... . . . 6-1

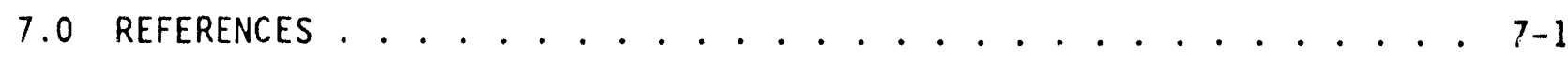




\section{LIST OF TERMS}

$\begin{array}{ll}\text { ALARA } & \text { as low as reasonably achievable } \\ \text { CBRS } & \text { component based recali system } \\ \text { DMF } & \text { Dry Materials Facility } \\ \text { DOE } & \text { U.S. Department of Energy } \\ \text { DST } & \text { double-shell tank } \\ \text { FSAR } & \text { final safety analysis report } \\ \text { FTS } & \text { Feed Transfer System } \\ \text { GDF } & \text { Grout Disposal Facility } \\ \text { GPF } & \text { Grout Processing Facility } \\ \text { GTF } & \text { Grout Treatment Facility } \\ \text { JCS } & \text { Job Control System } \\ \text { LCT/MM } & \text { liquid collection tank/mixer module } \\ \text { LDCRS } & \text { leachate detection/collection and removal system } \\ \text { M\&TE } & \text { measurement and test equipment } \\ \text { MEL } & \text { master equipment list } \\ \text { MIP } & \text { maintenance implementation plan } \\ \text { NIST } & \text { National Institute of Standards and Technology } \\ \text { OJT } & \text { on-the-job training } \\ \text { PM } & \text { preventive maintenance } \\ \text { PSW } & \text { phosphate/sulfate waste } \\ \text { PIH } & \text { portable instrument house } \\ \text { SEL } & \text { safety equipment list } \\ \text { WHC } & \text { Westinghouse Hanford Company } \\ & \end{array}$


WHC-SP-0918, Rev. 0

This page intentionally left blank. 
WHC-SP-0918, Rev. 0

\section{MAINTENANCE IMPLEMENTATION PLAN FOR THE GROUT FACILITY}

\subsection{EXECUTIVE SUMMARY}

The objective of the Maintenance Implementation Plan (MIP) is to describe how the Grout Treatment Facility will implement the requirements established by U.S. Department of Energy (DOE) Order 4330.4A, Ma intenance Management Program, Chapter 2.0 Nuclear Facilities (DOE 1990). The plan provides a blueprint for a disciplined approach to implementation and compliance.

Each element of the order is prioritized, categorized, and then placed into one of three phases for implementation.

\section{PHASE I}

Those elements that must be accomplished first in order to provide the critical infrastructure on which to build a successful program. These elements include, but are not limited to, administrative and technical policies and procedures, training requirements, the planning, scheduling and control and calibration of Measurement and Test Equipment (M\&TE) These elements and related subelements are described in detail in Section 4.0 of this MIP with a time-1ine schedule for accomplishment in Section 6.0.

\section{PHASE II}

Those elements that require the implementation of one or more of the Phase I elements and/or completion of other actions by functions such as Plant Engineering and Quality Assurance. These elements are discussed in general in Section 4.0 of the MIP and are identified for future action on the schedule in Section 6.0 .

\section{PHASE III}

Those elements that require completed actions in Phase I and II, and additional actions for implementation criteria by completing actions in Phase I and II. These elements are also generally discussed in Section 4.0 of the MIP and are identified on the schedule in Section 6.0.

In addition to the elements described in Chapter 2.0 of the order, the MIP also addresses how the graded approach to maintenance will be used. Section 3.0 of the plan separates facility structures, systems, and components into four separate categories: safety, process, facility systems not related to safety or the process, and other parts of the facility infrastructure. It describes the level of detail that must be applied to each of the categories, the priority that must be assigned to preventive and corrective maintenance reilated to these categories. Also, it describes the process used to determine the category assigned to structures, systems and components. 
Maintenance management practices identified as not fully supporting the recommended policies of DOE Order $4330.4 \mathrm{~A}$ will be evaluated using a graded approach addressing the most cost-effective level and manner for implementation. The approach used will focus on assigned safety classifications and consequence of failure. Initial (interim) equipment safety classification assignments will be based on existing system classifications and preliminary evaluation of risk exposure. Final equipment and system safety classifications will be implemented as part of the formal risk analysis process.

Key maintenance program elements that will be initiated in fiscal year (FY) $1993 / 1994$ include (1) updating administrative procedures to reflect current facility missions, (2) developing a facility master equipment 1 ist (MEL), (3) upgrading personnel training and qualification, (4) developing and implementing a structured method for assignment of importance level to events and maintenance activities (graded approach), and (5) re-evaluating existing maintenance requirements and implementing necessary changes. Additional improvements will be addressed as part of the outyear budget preparation process and will be reflected by updates to the MIP.

In conclusion, the MIP provides a formal plan for implementation of DOE order $4330.4 \mathrm{~A}$. It is a living document that will be revised, as appropriate, to provide a tool for tracking and measuring progress toward implementation and compliance. 
WHC-SP-0918, Rev. 0

\subsection{INTRODUCTION}

\subsection{FACILITY DESCRIPTION}

Grout treatment is the process of mixing selected double-shell tank (DST) wastes with grout-forming solids, and possibly with liquid chemical additives, to form a grout slurry that is pumped into near-surface asphalt-coated vaults for solidification and permanent disposal. Selected DST wastes are disposed of in batch sizes (campaigns) of about 1 Mgal. The total grout volume when dry solids are mixed with 1 Mgal of liquid waste is about $1.4 \mathrm{Mgal}$. Each vault is designed to contain the $1.4 \mathrm{Mgal}$ volume required to complete a campaign.

The Grout Treatment Facility (GTF) is an existing waste management unit located partly in the 200 East Area and partly in the adjacent 600 Area of the Hanford Site. The Final Environmental Impact Statement (DOE 1987) refers to the GTF as the Transportable Grout Facility; this includes the Feed Transfer System (FTS), the Dry Materials Facility (DMF), the Grout Processing Facility (GPF), and the Grout Disposal Facility (GDF).

\section{Feed Transfer System}

Mixed wastes to be processed at the GTF are received in the GTF waste feed tanks (241-AP-102 and 241-AP-104) before each grout treatment campaign. The waste is sampled, analyzed, and characterized to ensure that it meets waste feed acceptance criteria before being qualified for treatment and disposal. Once accepted the waste is pumped from the waste feed tank to the GPF using a deep-well turbine pump. The waste solution is pumped through a $2-$ in. carbon steel transfer line ( $S N-621)$, which is encased within a secondary pipe that will contain any leak in the primary piping. Waste is fed from the DSTs at a rate of 23 to $54 \mathrm{gal} / \mathrm{min}$ to the liquid collection tank/mixer module (LCT/MM) at the GPF. Grout facility equipment located within 241-AP Farm consists of the in-tank-mixer pump (P102-3), the grout feed pump (P102-1) and their associated monitoring and process control instrumentation.

\section{Dry Materials Facility}

The DMF is a nonradiological facility that consists of the process equipment necessary to receive dry materials, blend the individual components together, and load the dry blend onto closed bulk transport trucks for transport to the GPF dry material storage bin where it is held until needed. The DMF consists of the $2400-E$ control room, dry material storage bins, material unloading areas, and compressor buildings.

\section{Grout Processing Facility}

The GPF receives and mixes the dry blend materials and the DST liquid waste feed into a grout slurry and pumps the slurry through distribution piping to the GDF. All radioactive functions at the GPF are consolidated within a single confinement structure LCT/MM. Waste from the DST is pumped to the grout mixer at a rate between $23 / 54 \mathrm{gal} / \mathrm{min}$. 
WHC-SP-0918, Rev. 0

The waste is mixed with specific formulated combinations of dry materials and liquid additives to optimize its waste content and aid in the grout distribution and hydration process. Dry blend materiai is fed into the grout mixer inlet in the LCT/Mixer module at a rate between 150 and $484 \mathrm{lb} / \mathrm{min}$, where it is mixed with the waste feed and 1 iquid additives to from a grout slurry. The resultant slurry is pumped through an encased pipe distribution line at 30 to $70 \mathrm{gal} / \mathrm{min}$ and deposited in the disposal vault at the GDF. The GPF consists of modular buildings which include the 243-G4 control room, the 243-G7 motor pit, the 243-Gl LCT/mixer module, and several other equipment modules. Trailers have been set up to provide office space, a lunch room, and change rooms for operations and maintenance personnel.

\section{Grout Disposal Facility}

The GDF vault retains the grout slurry while it solidifies, thus producing a large grout mass containing immobilized mixed wastes with an approximate volume of $1.4 \mathrm{Mgal}$. The inside dimensions of the concrete vault are approximately $123 \mathrm{ft}$. long, $50 \mathrm{ft}$. wide and $34 \mathrm{ft}$. high. The GDF includes distribution piping; disposar vault and leachate detection/collection, and removal system (LDCRS); excess water return piping and pumps; and control and power supply systems. The vault and vault liner and ventilation exhauster provide primary confinement; the LDCRS, which consists of a catch basin and iner, provides secondary confinement. The GDF is monitored by remote sensing instruments. Filtered exhaust is discharged from the vault through a powered ventilation system equipped with a stack. The GDF consists of vaults 218-E-16-101 through 105 and Portable Instrument Houses 1 through 3.

\subsection{MISSION}

A major mission of the DOE is to achieve permanent disposal of defense wastes at the Hanford Site with safe, envirormentally acceptable, and cost-effective disposal methods that meet the applicable regulations. The construction of the GTF is included as the preferred low-level waste disposal alternative in the Final Environmental Impact Statement.

\subsection{HISTORY/SCHEDULED LIFE}

Grout disposal operations were initiated in August 1988, phosphate/ sulfate waste (PSW) with a low radionuclide content was selectad for initial grouting to allow for a low-hazard demonstration of the Grout facility operation. Initial startup of the GPF revealed design deficiencies with the surge tank ventilation system. Design changes were implemented and the PSW grout campaign was completed on July 11, 1989. The GPF has been in a shutdown mode since then while new vaults are being built, and characterization activities for the DST waste feed are being completed.

The GTF will be in one of three modes at all times: (1) operation mode-grout processing is occurring; maintenance activity will be limited so as not to affect processing. Instrument calibrations and equipment preventive maintenance (PM) activities are complete and current; (2) shutdown mode--grout processing is not occurring; limited maintenance such as calibrating equipment, PMs and minor repair work can be completed at this time; (3) repair 
mode--the GPF is not available for grout processing; unlimited maintenance activities to include corrective maintenance and facility modifications, as required, to return the facilities to an operational mode.

The GTF equipment and systems were designed for minimal maintenance activities within radiological boundaries. The majority of the maintenance actions will be done by the Grout Maintenance Group which consists of a multicraft crew, plant engineer, supervisors, and the maintenance manager.

The disposal of current and projected inventories of DST waste may take up to 25 years to complete. During this time it is projected that vaults designed to contain about $43 \mathrm{Mgal}$ of waste must be constructed, filled, and administered as surface impoundments until closure as landfills. Four campaigns a year will be conducted to meet the Hanford Federal Facility Agreement and Consent Order; (known as the Tri-Party Agreement) (Ecology, et al., 1992).

Facility upgrades will be required to keep the facility operatins safely through its projected life cycle. Additional funding over and above operational maintenarice costs will be required to support these upgrades. 
WHC-SP-0918, Rev. 0

This page intentionally left blank. 


\subsection{DOE 4330.4A REQUIREMENTS IN ADDITION TO THOSE STATED IN CHAPTER II}

\subsection{IDENTIFICATION OF STRUCTURES, SYSTEMS, AND COMPONENTS INCLUDED WITHIN THE MAINTENANCE PROGRAM}

Structures, systems, and components of the Grout Processing Facility are discussed in various facility documents (e.g. final safety analysis report, safety equipment list, and software manuals). The level of maintenance and overview required to perform maintenance is identified by the safety designation assigned to the structure, system, or component. When no such document exists, Engineering will make the determinations based on established guidelines and parameters. Currently facility documentation of this type is less than adequate. There is no MEL or equipment history files at this time. Action is in progress to resolve these issues. An existing safety equipment list (SEL) is in place and will be maintained to reflect any changes in the facility as required. The current Job Control System (JCS) is the only current source of failed equipment history file.

\subsection{SYSTEMATIC ANALYSIS DESCRIBING SYSTEM/COMPONENTS INCLUDED WITHIN THE PREVENTIVE MAINTENANCE PROGRAM, AND DETERMINATION OF FREQUENCY OF MAINTENANCE ACTIONS}

An effective preventive maintenance program is an essential part of an efficient, cost-effective maintenance program. A systematic analysis of each system and component must be performed to determine the value added by performing or not performing preventive maintenance for specific systems or components. This analysis must consider the consequence of failure, safety and environmental concerns, and the cost of performing preventive maintenance rather than letting the system or component run until failure.

The frequency at which preventive maintenance is performed also must be established. Frequencies shall be established using manufacturer's data considering equipment history, engineering judgment and safety requirements established for the specific system or component.

A preventive maintenance strategy will be developed to provide written guidance for determining what equipment will receive preventive maintenance and how the frequency will be determined (see Section 4.4, Types of Maintenance).

\subsection{MAINTENANCE SELF-ASSESSMENTS}

Performance-based maintenance self-assessments have been incorporated into the Grout Facility (MIP). These self-assessments will be performed, as a minimum, on a bi-annual basis that coincides with the revision of the MIP. The assessment will measure the effectiveness of the maintenance program based on the elements 1 isted in chapter II of DOE Order $4330.4 A$ (DOE 1990). In addition, the assessment will be used to measure progress based on the results of previous assessments. These assessments will consist of a combination of 
activities ranging from desktop comparisons to field observations. Assessments will be augmented further by periodic program surveillances by senior management and other responsible overview organizations. Results of all assessments and surveillances will be reviewed by appropriate levels of management, necessary corrective actions initiated, final assessment reporis issued, and changes to the MIP made as necessary.

\subsection{GRADED APPROACH TO MAINTENANCE}

For this plan, graded approach is defined as where the depth of detail required and the magnitude of resources expended for a particular maintenance management element is commensurate with the elements importance to safe and reliable operations, environmental compliance, safeguards and security, programmatic mission, facility preservation, and/or otner facility specific requirements.

This implementation plan is based on a graded approach considering facility mission assignment, facility/equipment safety classification, and results of risk analysis performed on that facility or equipment, to determine the extent of control and level of maintenance or repairs necessary.

The following discussion outlines the methods used for near-term (interim) and long-range (formal) implementation of the DOE order.

\section{NEAR-TERM PLAN (INTERIM)}

Initially the programmatic aspects of the existing maintenance program will be enhanced in those areas identified by self-assessment as not meeting the intent of the order. Once the program administrative controls and procedures are in place, attention will be directed to maintenance activities at the facility, system, and equipment level.

Concurrent with the activities directed to the programmatic (element) level of the maintenance program, development of facility MEL will be initiated, based on field surveys of principle in-service equipment.

- Initially, existing system safety classifications will be applied to all equipment within the system. As the MEL is developed, evaluation of equipment within each system will be made to adjust the assumed safety classification and to assign an interim risk category. These evaluations and interim classification and risk assignments will be performed by appropriate engineering, safety, operations, quality, and maintenance organization personnel.

With the equipment identified, interim safety classifications and risk categories assigned, required maintenance procedures will be developed and revised. Definitive activity schedules will be developed, using the graded approach to effectively use available resources and budgets available, for development and implementation of these procedures and maintenance activities. 


\section{LONG-RANGE PLAN (FORMAL)}

The MEL will be finalized and examined to ensure all appropriate equipment has been identified. Equipment safety risk analysis will be conducted to determine consequence of system and/or component failure and to establish the level of maintenance appropriate to that risk level. Changes to equipment safety classifications and risk categories previously assigned will be made as necessary. Procedures generated and maintenance activities initiated in support of preliminary safety classifications assignments will be reviewed to ensure appropriate levels of control and maintenance have been applied.

The risk categories to be assigned will be in accordance with a structured method which establishes a graded approach to categorizing severity of conditions, consequence of failure, and assignment of response priority for that condition.

Safety Class 1--Systems, components, and structures, including portions of process systems, whose failure could result in a threat to the environment, health, and safety of the public. Activities will require the highest level of work instruction detail, craft skills, and supervision. The Grout facilities do not contain any Safety Class 1 items at this time.

Safety Class 2--Systems, components, and structures, including portions of process systems not defined as Safety Class 1 , which could result in a threat to onsite worker, safety and the environment. Activities will require a moderate level of work instruction detail, craft skills, and supervision.

Safety Class 3--Systems, components, and structures, including portions of process systems not defined as Safety Class 1 or 2 , which could result in a threat to the health and safety of facility workers and radioactive, chemical, or thermal releases to the environment. Activities will require normal level of work instruction detail, craft skills, and supervision commensurate with the complexity of the work activity.

Safety Class 4--Systems, components, and structures whose failure has no significant importance to safety, health, or environmental protection. Activities will require a minimal level of work instruction detail, craft skills, and supervision. 
WHC-SP-0918, Rev. 0

This page intentionally left blank.

$3-4$ 
WHC-SP-0918, Rev. 0

\subsection{DOE ORDER 4330.4A CHAPTER II REQUIREMENTS}

As shown in the Executive Summary, the improvement actions specified in this section of the MIP are not designed to immediately convert the Grout Treatment Facility maintenance program to the level described in DOE Order $4330.4 \mathrm{~A}$, but rather to initiate the step changes required for compliance. Using a weighted analysis (graded approach), the 18 elements of DOE Order $4330.4 \mathrm{~A}$, Chapter II, have been put in one of three phases of implementation. Safety, operational significance, and resource availability were among the factors for phase determination. Immediate across-the-board application of all portions of the order would overburden existing resources and commitments, which, in turn, potentially jeopardizes personnel and environmental safety. The MIP provides a method for continued and sustained improvement. The application of self-assessments and corrective action activities referenced in Section 3.0 of the MIP will be used to monitor and update the plan.

\subsection{MAINTENANCE ORGANIZATION AND ADMINISTRATION}

This section of the MIP describes how Grout Maintenance ensures that a high level of performance in maintenance will be achieved.

\subsubsection{Maintenance Organization Policies}

Objective: Develop and implement a hierarchy of policies and procedures that specifically address maintenance programs. These policies will define the relationship between facility policies and maintenance, policies and implementing procedures and the roles and responsibilities of organizations and positions as they relate to the maintenance program.

Discussion: Currently, policies affecting Grout Facility Maintenance are distributed throughout numerous Westinghouse Hanford Company (WHC) manuals. These policies do define responsibilities between policies and procedures, the roles and responsibilities of organizations, individual positions are well defined. However, this information is not centrally located, making it difficult to retrieve.

Improvement: Consolidate maintenance policies into a minimum number of manuals/procedures where practical. Convey the location of essential policies to the appropriate maintenance personnel. 


\subsubsection{Maintenance Strategy}

Objective: Develop a strategy based on an integrated approach to maintenance, with long-range planning as the cornerstone where work scope is well defined to develop accurate funding and staffing levels consistent with the identified scope of work. The strategy will describe the working relationships of interacting organizations, as well as personnel and procedural interfaces. It will also describe the responsibility, authority, and accountability of the supporting organizations.

Discussion: Funding and staffing requirements estimates are based on identified work scope. Scope must be negotiated to be consistent with available funding and staffing limits.

Improvement: Agree only to perform work scope consistent with approved funding and staffing. Document identified work scope that will not be performed without additional funding and staff. Provide program management with formal documentation of impacts that will be experienced if additional funding and staffing are not approved.

\subsubsection{Staffing Resources}

Objective: Assemble and maintain a maintenance organization staff selected to prescribed qualification criteria commensurate with the facility mission(s).

Discussion: Position qualifications are established by prescribed position requirements, credentials of candidates are screened, and final selections made by hiring manager. Staff quantities are determined by projected work activities and approved budget levels.

Extensive sharing of personnel between organizations is used to offset cost of excess personnel not relocated and to satisfy needs for skills/quantities not available from within our organization.

Improvement: Existing maintenance program practices satisfy intent of stated objective. Need for additional improvement or enhancement will be evaluated as part of ongoing selfassessment program.

\subsubsection{Goals and Objectives}

Objective: Develop and maintain goals and objectives for the maintenance program that are achievable and measurable. Measure performance and effectiveness to these goals and objectives in a manner such that the information obtained can be used for further improvement. 
Discussion: Specific goals identified include the following: Development of the DOE 4330.4A MIP, allocation of sufficient maintenance space, upgrade the job control system, improve procedures, implement a cost-effective spare parts program, upgrade Grout shop equipment improve material control and manage the corrective maintenance backlog to minimize completion time of deficiencies. These goals are realistic and achievable. The current system will permit adjustment of the expectations if conditions change in the process of improving the program.

Improvement: Improve tracking and trending of methods to measure performance and effectiveness of established goals.

\subsubsection{Accountability}

Objective: Ensure that all maintenance personnel understand and acknowledge their personal level accountability, and that expectations have been well communicated and understood by a11. Good and substandard performance is recognized with immediate corrective action being taken for substandard performance. Corrective action for substandard performance should be positive in order to foster improvement.

Discussion: Employee meetings, as well as staff and unit level meetings are conducted routinely to communicate expectations and foster accountability at a 11 levels. Systems are in place for the recognition of performance.

Both good performance and substandard performance are recognized immediately. Personnel performance is documented in annual performance appraisals.

Improvement: Continuous monitoring of these activities is required to assure consistency with continuous positive reinforcement of expectations and levels of accountability. These activities are considered to be routine and part of the normal process operating the maintenance program.

\subsection{TRAINING AND QUALIFICATION OF MAINTENANCE PERSONNEL}

This section of the MIP describes how Grout Facility Maintenance will establish a maintenance training and qual ification program consistent with DOE Order 5480.5, Safety of Nuclear Facilities, and DOE Order 5480.20 Personnel Selection, Qualification, Training and Staffing Requirements at DOE Reactor and Non-Reactor Facilities, and how they are implemented to develop and maintain the knowledge and skills needed by maintenance personnel to effectively perform maintenance activities. Westinghouse Corporate has communicated its expectations in this area to all Westinghouse governmentowned, contractor-operated locations. 


\subsubsection{Responsibilities}

Objective: The Grout Facility Maintenance organization is responsible and accountable for determining the training needs of each individual in the Maintenance organization. The training organization identifies existing programs, develops new training programs and presents the training using in-house personnel or vendor supplied personnel when appropriate.

Discussion: The training responsibilities of the maintenance and training organizations are well understood. However, adequate policies and procedures do not currently exist to provide specific guidance for the development and implementation of an effective training and qualification program.

Improvement: Develop and implement policies and procedures that clearly define the responsibility of the maintenance and training organizations as they relate to the identification, development, and implementation of essential training and qualification programs.

\subsubsection{Maintenance Training Programs}

Objective: Develop and maintain maintenance training programs based on systematic job analysis incorporating requirements based on established industrial guidelines.

Discussion: The Training organization performs job analys is using a standard format. Training programs are developed using best industrial practices. Manufacturers are routinely consulted as part of program development. There are no current job analysis on record for Grout Facility Maintenance job descriptions. Formal training programs have not been implemented based on job description.

Improvement: Perform job analysis for each job description. Using the results of the job analysis, baseline training requirements incorporating best industrial practices.

Develop and document baseline training programs/requirements based on the results of the job analysis.

\subsubsection{Training Schedules and Support}

Objective: Training shall be coordinated in such a manner that permits maximum impact from the training with minimal impact on the facility. 
Discussion: Training is scheduled and coordinated through a single facility training coordinator. The training coordinator uses Hanford Site records and the Hanford Site recall report to determine retraining requirements. There are no exceptions to the required training. Facility instructors are used to provide facility-specific training, such as the facility-specific emergency $p l$ an and the facility specific lock-and-tag procedure.

Improvement: Coordinate with training organizations to schedule classes of less than 8 hours such that other short classes are available during the sarne day and use facilities closer to work locations to minimize lost work time.

\subsubsection{On-the-Job Training}

Objective: Formal on-the-job training (OJT) programs defining specific requirements for final qualification of personnel must be established. OJT training shall be conducted by qualified instructors in accordance with approved training plans.

Discussion: Currently maintenance OJT is only provided for site hazardous waste, site-specific radiation zone training and the building emergency plan. No formal OJT trainer training is provided, and the only OJT lesson plans are for hazardous waste workers.

Improvement: Develop formal OJT training program and identify activities requiring $0 \mathrm{JT}$.

\subsubsection{Qualification}

Objective: Develop a program that will establish the qualifications for persons working on specific pieces of equipment. These qualifications also will apply to contractor personnel performing maintenance work.

Discussion: The final safety analysis report (FSAR) (WHC 1992 Chapter 10) shows the training matrix for personnel designed to work at the Grout Facility. However, there are no procedures in place that identify qualification requirements for maintenance personnel assigned to perform specific work.

Improvement: Develop and implement procedures that identify qualification requirements for persons assigned specific work. 


\subsubsection{Training in Root Cause Analysis}

Objective: The Maintenance organization will have a core group of personnel in the Maintenance Engineering group that will be formally trained in root cause analysis.

Discussion: Currently, there are no employees in the Maintenance Engineering group that have had formal training in root cause analysis. Management must determine how many and who will receive the training. Employees trained in rootcause analysis are available from Facility Operations to support maintenance actions if required.

Improvement: Train a core group of maintenance engineers in standard methods of root cause analysis.

\subsubsection{Training Program Approval, Effectiveness and Feedback}

Objective: Management reviews and approves all training programs. Through classroom and field observation, management measures the effectiveness of training programs and provides feedback to the Training organization and maintenance management related to the quality and effectiveness of the training program.

Discussion: Currently training programs are approved by management. The effectiveness of the programs are measured by observing classroom and on-the-job performance. Feedback related to training is provided by management audits of training sessions and formal critiques of training sessions. However, management needs to increase its emphasis in this area.

Improvement: Maintenance managers should attend training classes for evaluation of the effectiveness of training programs and to provide feedback to the training organizations.

\subsubsection{Management and Supervisory Training}

Objective:

Provide a training program for management that develops management and leadership skills, as well as technical competence.

Discussion: All managers and supervisors are scheduled to attend at least one management or leadership class per year. This is documented and tracked as part of the annual performance appraisal process. Managers and supervisors are encouraged to attend technical training classes that pertain to their area of responsibility. 
WHC-SP-0918, Rev. 0

Improvement: Develop a required training matrix of suggested classes that are based upon the level of management and their position assignments.

\subsection{MAINTENANCE FACILITIES, EQUIPAENT AND TOOLS}

This section of the MIP describes how Grout Facility Maintenance ensures that maintenance "acilities, equipment, and tools, efficiently support facility maintenance and maintenance training.

Objective: The objective of this element is to obtain and maintain adequate facilities to support the maintenance infrastructure. This includes adequate shop space to support projected staffing along with planned increases in shop equipment, discrete equipment storage and staging areas capable of supporting day-to-day operations. This includes adequate office area to support managers, supervisors, individual contributors, and clerical staff. Offices are to be adequately equipped with computers, fax machines, and copy machines, to efficiently support the maintenance program.

Discussion: Shop spaces, laydown areas and equipment storage areas are less than adequate. In addition, office space is not sufficient to support current and planned staff.

Improvements: Management is currently reviewing space use within the facility. Studies are underway to determine future needs. Initial requirements have been identified to include mobile trailers to provide administrative office space, material storage, and a small maintenance shop. Occupancy is expected in mid-1993. Additional space requirements will be studied by engineering. Funding to implement the engineering recommendations will be aggressively pursued.

\subsection{TYPES OF MAINTENANCE}

This section of the MIP describes how Grout Facility Maintenance will employ a proper balance of corrective and preventive maintenance to provide a high degree of confidence that facility equipment degradation is identified and corrected, that equipment life is optimized and the maintenance program is cost effective.

Objective: Develop and maintain a MEL that identifies all equipment associated with facility structures, systems, and components. Include special tools and equipment required to perform maintenance. Identify and achieve the correct balance between corrective and preventive maintenance and identify the criteria used to determine that balance. Determine how preventive maintenance actions are selected for specific items on the MEL. Develop and implement methods for determining preventive maintenance 
frequencies. Maintenance types shall be categorized as corrective, preventive, or predictive.

Discussion: Currently, there is no MEL for the facility. Preventive maintenance is scheduled using a computer-based recall system. When preventive maintenance is not performed because of outages or corrective maintenance, they are incorporated in the restart requirements or as part of the post-maintenance testing process. Currently, the Grout Facility Maintenance program is focused on preventative maintenance activities required by specifications, code requirements and corrective maintenance as identified. No planned predictive maintenance activities have been initiated.

Improvement: Development of the MEL is critical to this element for its use as a history file which will determine the effectiveness of the previous maintenance program frequencies. Plant Engineering has initiated action to develop MEL and work is in progress. Grout Maintenance/ Engineering must initiate actions to develop policies that describe the preventive maintenance process. This policy should address the methods used to determine what preventive maintenance actions are required and methods used to determine frequency. Expand maintenance program (using graded approach) to address predictive maintenance activities.

\subsection{MAINTENANCE PROCEDURES}

This section describes how Grout Facility Maintenance prepares and uses maintenance procedures and other work related documents (e.g., drawings and instructions) to provide appropriate work direction that ensures maintenance is done safely and efficiently.

\subsubsection{Procedure Development and Writing}

Objective: Procedures will be written for any component or system that has safety significance, degrades facility reliability, or is associated with personnel or equipment hazard. These procedures will be written in a standard format with the level of detail ranging from specific step-by-step instructions to general work instructions. In some instances, special formats suci: as checklists and flow diagrams may be used in place of standard procedures. The level of detail will be consistent with the degree of difficulty.

Discussion: Currently, there are procedures in place for work that is complex in nature or requires specific technical data to be performed (e.g., instrument calibrations, pressure tests). Many of the existing procedures are poorly 
written and are not user friendly. The Grout Facility is in the process of revising all maintenance procedures. A standard format is used for writing procedures with checklists, diagrams and flow charts included when appropriate. Detailed work instructions are included in work packages when specific procedures are not in place.

Improvement: Complete the effort of revising existing maintenance procedures and assure that format and level of detail required are included in these procedures.

\subsubsection{Procedure Verification}

Objective: Perform reviews of maintenance procedures to ensure proper format and technical accuracy, assure that these reviews are performed after the procedure has been written. Verification will be performed by persons other than the author.

Discussion: All procedures are reviewed for technical content. Verification is performed after the procedure is written, by an independent reviewer. The format is not currently reviewed as part of this process.

Improvement: Existing maintenance program practices satisfy intent of stated objective. Need for additional improvement or enhancement will be evaluated as part of ongoing selfassessment program.

\subsubsection{Procedure Validation}

Objective: $\quad$ Procedures are reviewed for usability and correctness to ensure sufficient and understandable instructions are provided and are compatible to the equipment and task specified.

Discussion: Before issuance, procedures are user tested by actual performance, simulated performance, or table top review. Table top reviews are allowed only as a last resort and with management authorization.

Improvement: Existing maintenance program practices satisfy intent of stated objective. Need for additional improvement or enhancement will be evaluated as part of ongoing selfassessment program.

\subsubsection{Procedure Approval}

Objective: Procedures are reviewed to applicable specifications and administrative procedures and approved by appropriate levels of management. 
Discussion: Procedures are written to an appropriate safety classification and risk (impact) level. The impact level criteria defines the extent of review. The highest degree of overview is given to safety related procedures while the lesser degree of overview is given to non-safety related procedures. As a minimum, procedures are reviewed and approved by maintenance, a cognizant engineer, and the cognizant engineer's manager.

Improvement: Existing maintenance program practices satisfy intent of stated objective. Need for additional improvement or enhancement will be evaluated as part of ongoing selfassessment program.

\subsubsection{Procedure Use}

Objective: Procedure control is established ensuring availability and currency of the procedures to be used. Procedure compliance requirements are clearly stated, communicated, and understood by users.

Discussion: Procedures are controlled from the initial development request, through the review and approval cycle, to distribution of the procedure. Procedure control is continued from issuing the procedure for use, through completion, and archiving the completed procedure.

Procedural compliance requirements are clearly defined and reiterated through re-occurring training and coaching.

Improvement: Existing maintenance program practices satisfy intent of stated objective. Need for additional improvement or enhancement will be evaluated as part of ongoing selfassessment program.

\subsubsection{Procedure Control, Periodic Review and Revision}

Objective: Maintenance procedures are controlled in the master computer file to assure that only the most recent revision of procedures are used. Periodic reviews are required to ensure that they contain the most current requirements and technical data. Procedures are revised through a formal process to ensure that changes are incorporated in a timely manner.

Discussion: Procedures are issued from a controlled data base. Currently procedures are reviewed and revised if conditions change, the procedure cannot be performed as written, or for periodic review as designated by the impact level of the procodiure. 
Improvement: Existing maintenance program practices satisfy intent of stated objective. Need for additional improvement or enhancement will be evaluated as part of ongoing selfassessment program.

\subsection{PLANNING, SCHEDULING AND COORDINATION OF MAINTENANCE}

This section describes how Grout Facility Maintenance will develop an effective system for planning, scheduling, and coordinating maintenance activities to ensure that maintenance is accomplished in a timely manner; improve maintenar:-e efficiency; reduce exposure to hazardous situations (ALARA); and increase equipment available.

\subsubsection{Planning for Maintenance Activities}

Objective: Establish and maintain a dedicated planning staff to support maintenance activities. These planners will be trained in their responsibilities associated with work package preparation and post-maintenance review.

Discussion: Dedicated planners have been assigned to the Grout facility. These planners have been trained in their responsibilities related to work package preparation and post work reviews. The existing JCS conforms to the requirements of DOE Order $4330.4 \mathrm{~A}$.

Improvement: Existing maintenance program practices satisfy intent of stated objective. Need for additional improvement or enhancement will be evaluated as part of ongoing selfassessment program.

\subsubsection{Scheduling Maintenance Activities}

Objective: Maintenance is based on accurate planning consistent with plant priorities and the effective control of the work backlog, work is scheduled in such a manner that resources are effectively used and employee exposure to hazardous situations is minimized (ALARA). Work scheduled during facility outages should be in such a manner that the maximum effort is performed within the identified time constraints.

Discussion: Procedurally, the elements required for effective scheduling and effective control of the work backlog are in place. Work scheduling addresses radiological exposure and exposure to other hazardous materials and conditions. The use of outage scheduling between waste processing campaigns is 1 imited. Additional emphas is needs to be placed on setting realistic priorities and more disciplined control of the backlog. 
Iinprovenent: Revise the schedule process to more effectively address plant priorities, including effective control of the work backlog. Implement outage scheduling where applicable. Resource coordination is to be a prime consideration.

\subsubsection{Coordination of Maintenance Activities}

Objective: Plan and schedule maintenance activities so that resources and time constraints are maximized, and will ensure that support organizations are aware of their part/responsibilities so they are fully prepared and committed to meet work schedules.

Discussion: Plan of the day/week meetings are held to identify current and future needs for resources and establish time frames when the work is to be performed. Resources are identified on the work packages.

Improvement: Clearly communicate the expectations and responsibilities associated with work coordination to everyone involved.

\subsubsection{Outage Planning, Scheduling and Coordination}

Objective: Outage planning, scheduling, and coordination fall into two categories: planned outages and forced outages. Successful outage planning has two common elements: defined responsibilities for planning, scheduling and coordination and a standard method of identifying nonoutage work that will be performed during the outage.

Discussion: Currently, a formal outage program for maintenance work does not exist in Grout. Outage type planning is used before restarting selected processes. All work required for startup is identified, including work identified in the backlog. Track outage work code under JCS on a separate schedule.

Improvement: Develop a process defining planned and forced outages. The process must identify planning, scheduling, and coordination responsibilities. In addition, it must describe the method used to determine which non-outage work will be performed during the outage.

\subsection{CONTROL OF MAINTENANCE ACTIVITIES}

This section of the MIP describes how Grout will display management directed and delegated involvement in control of maintenance activities to ensure that maintenance practices are effective in maintaining safe and reliable facility operation. 


\subsubsection{Work Control Procedure}

Objective: Develop and maintain a work control process that includes corrective maintenance, modifications, in-service tests, surveillance, and preventive maintenance actions. The procedure addresses a description of the work request form, who can initiate and approve the work request, a description of the work control process, supervisory responsibility for controlling maintenance, the priority system, and special conditions that my be encountered (e.g., confined space entry, excavation).

Description: The current system is a combined manual and computerized process with built in interface. It contains all of the elements described in the objective.

Improvement: Existing maintenance program practices satisfy intent of stated objective. Need for additional improvement or enhancement will be evaluated as part of ongoing selfassessment program.

\subsubsection{Work Request}

Objective: Develop and maintain a work request system that identifies the work required, establishes plant acceptance, identifies priority, provides work instructions, instructions for retest and documents plant approval of the work.

Description: The work request system addresses pertinent elements such as equipment identification, problem identification, permits required, work resolution, retest requirements, safety and work authorizations. Upon completion of work items such as retest and acceptance criteria, signoff approvals are addressed.

Improvement: Existing maintenance program practices satisfy intent of stated objective. Need for additional improvement or enhancement will be evaluated as part of ongoing selfassessment program.

\subsubsection{Supervisor of Maintenance Activities}

Objective: Maintenance supervisors will assure that maintenance is being conducted in accordance with DOE and facility policies and procedures. Problems observed are analyzed and feedback provided to prevent recurrence.

Discussion: Supervisors assign work in accisdance with daily schedule. Pre-job briefings are held, stressing safety and ALARA principles. Supervisors routinely visit work sites to observe progress and to ensure work is being accomplished 
safely and in accordance with work instructions. Due to the geographic locations of the Grout facilities, transportation for supervisors to visit work sites is inadequate. Currently Grout Maintenance only has two vehicles to transport 15 people and their equipment to the 4 various work sites.

Improvement: FY93 capital money has been identified and approved for the purchase of vehicles. One of these vehicles must be identified for maintenance use to allow the supervisors access to the work sites.

\subsubsection{Review of Completed Work Requests}

Objective: Completed work packages are reviewed to verify all work items, including post maintenance testing and inspections, have been completed in an acceptable manner prior to returning system or equipment to service.

Discussion: Maintenance supervisor and shift manager review work packages for completeness before returning system or equipment to service. Additional reviews as required by the assigned impact level, are performed by engineering, $Q A$, and safety part of the document review and close out process.

Improvement: Existing maintenance program practices satisfy intent of stated objective. Need for additional improvement or enhancement will be evaluated as part of ongoing selfassessment program.

\subsubsection{Temporary Repairs}

Objective: Temporary repairs are accomplished and controlled to the same level as permanent repairs.

Discussion: All Grout work activities including temporary repairs are controlled in accordance with the established JCS.

Improvement: Existing maintenance program practices satisfy intent of stated objective. Need for additional improvement or enhancement will be evaluated as part of ongoing selfassessment program.

\subsubsection{Control of Nonnuclear Facility Contractor and Subcontractor Personnel}

Objective: Contractor and subcontractor personnel work under the same controls and standards as facility personnel. Contractor managers are held accountable for the work performed by their personnel. Facility management reviews the work of contractor and subcontractor personnel while preparing to 
do work, at the work site, and during post-maintenance testing and acceptance.

Discussion: All contractor, subcontractor work is performed and tracked using the facility Job Control System. Contractor management is held respunsible and accountable for work performed by their personnel. Facility management, through a liaison organization, is involved with work preparation and field work performed by subcontractor personne1. Facility management overviews post-maintenance testing and acceptance through acceptance testing and operational performance testing.

Improvement: Existing maintenance program practices satisfy intent of stated objective. Need for additional improvement or enhancement will be evaluated as part of ongoing selfassessment program.

\subsection{POST-MAINTENANCE TESTING}

This section describes how Grout incorporates post-maintenance testing to verify that components will fulfill their design function when returned to service after maintenance

\subsubsection{Post-maintenance Test Requirements}

Objective: Work control program addresses control and documentation of post-maintenance testing. Work requests provide specific instructions for test and acceptance criteria.

Discussion: Post-maintenance testing is an integral part of the work package planning process. Appropriate testing requirements and methods are provided to ensure equipment repairs are satisfactory and that it will perform its designed function. Where appropriate remote operation verification is included in post-maintenance testing verifications.

Improvement: Existing maintenance program practices satisfy intent of stated objective. Need for additional improvement or enhancement will be evaluated as part of ongoing selfassessment program.

\subsubsection{Post-maintenance Test Scope}

Objective: All maintenance activities are reviewed for applicability of post-maintenance testing and appropriate testing instructions (and acceptance criteria) is provided. 
Discussion: All maintenance activities, preventive and corrective, include post-maintenance testing as is appropriate to verify ability to function prior to returning equipment or system to service. Rigor of testing is commensurate with the importance of the equipment and its safety-related classification. Need and extent of testing is reviewed and approved by engineering, operations, and other appropriate organizations.

Improvement: Existing maintenance program practices satisfy intent of stated objective. Need for additional improvement or enhancement will be evaluated as part of ongoing selfassessment program.

\subsubsection{Post-maintenance Test Control}

Objective: Work control program addresses control of post-maintenance testing covering all conditions of single or multiple organization involvement or when testing is deferred until a later date.

Discussion: Equipment is not returned to service until all work package conditions, including post-maintenance testing, have been satisfied.

Improvement: Existing maintenance program practices satisfy intent of stated objective. Need for additional improvement or enhancement will be evaluated as part of ongoing selfassessment program.

\subsubsection{Post-maintenance Test Performance, Documentation, and Acceptance}

Objective: Post-maintenance testing is performed in accordance with approved work package instructions (or preventive maintenance procedure) and completion is documented.

Discussion: Equipment is returned to service only after completion and closeout of the work package or preventive maintenance procedure which includes post-maintenance testing requirements. Close out of work package (or procedure) includes review and acceptance by appropriate organizations such as engineering, QA, operations, and maintenance.

Improvement: Existing maintenance program practices satisfy intent of stated objective. Need for additional improvement or enhancement will be evaluated as part of ongoing selfassessment program. 


\subsection{PROCUREMENT OF PARTS, MATERIALS, AND SERVICES}

Describes how Grout Facility Maintenance will ensure that parts, material, and services required for maintenance activities will be available when needed.

Objective: Ensure that all Grout Facility personnel who are directly involved with the procurement of parts, materials, and services totally comply with procurement policies and procedures.

Discussion: The procurement of parts, materials, and services is a service provided by a single procurement organization. All procurement actions are conducted using existing government regulations. Facility personnel requesting procurement actions are required to use a standardized format as directed by the procurement organization.

Improvement: Personnel responsible for procurement actions are fully trained in existing policies and procedures. No further action is required at this time.

\subsection{MATERIAL RECEIPT, INSPECTION, HANDLING, STORAGE RETRIEVAL AND ISSUANCE}

This section describes how Grout Facility personnel implement policies and procedures consistent with DOE Order 5700.6C, "Qual ity Assurance," for al1 phases of receiving, inspecting, handling, storing, retrieving and issuing equipment, parts, and materials from the time an item is received until it is installed in the facility.

\subsubsection{Receipt Inspection}

Objective: Receipt inspections of materials and equipment is performed prior to acceptance for use or storage, verifying items delivered conform to all procurement document requirements and are in good condition.

Discussion: Procedures are in place to support all aspects of receipt inspections. Deviations are approved and documented by appropriate organizations. Material segregation is accomplished by tagging and/or physical separation to designate material status. Good business practices are applied using a graded approach for the degree of inspection required for material or equipment based on assigned safety classification.

Improvement: Existing program practices satisfy intent of stated objective. Need for additional improvement or enhancement will be evaluated as part of ongoing self-assessment program. 


\subsubsection{Handling}

Objective: $\quad$ Procedures are provided for items requiring special handling. Procedures include all information necessary to prevent damage.

Discussion: Procurement documents contain special handling requirements recommended by the vendor. Engineering also may apply special handling requirements. Procedures are in place to apply administrative controls applicable to the safe handling of material or equipment.

Improvement: Existing program practices satisfy intent of stated objective. Need for additional improvement or enhancement will be evaluated as part of ongoing self-assessment program.

\subsubsection{Storage Material and Equipment}

Objective: Material and equipment is stored in a manner to provide maximum protection but remains readily available for issue. Safety related equipment is segregated from nonsafety items to prevent improper usage.

Discussion: Material and equipment is stored using good management practices and industry standards assuring material and equipment protection from adverse elements and ease of access. Material with controlled shelf life is monitored and re-ordered as necessary with out-dated material removed from stock and disposed of. Preventive maintenance procedures are prepared but have not been fully implemented.

Improvement: Evaluate and implement a maintenance program for stored materials and equipment.

\subsubsection{Retrieval and Issuance}

Objective: Parts, materials, and equipment removed from storage are handled to the same requirements applied at time of receipt. Stores inventory system is in place to identify available materials and equipment and is available to using organizations such as planning and engineering.

Discussion: Procedures are in place to ensure that the correct application of material and equipment for the task are available. Material traceability is ensured through material marking and tagging, as appropriate, to documents available on file. Quality Control is involved in the issuance process as is appropriate to the safety classification of material involved. 
Improvement: Existing maintenance program practices satisfy intent of stated objective. Need for additional improvement or enhancement will be evaluated as part of ongoing selfassessment program.

\subsection{CONTROL AND CALIBRATION OF MEASURING AND TEST EQUIPMENT}

This section of the MIP describes how Grout Facility personnel will implement a program for control and calibration of M\&TE that is consistent with DOE Order 5700.6C, Quality Assurance, (DOE 1991b) and ensure the accurate performance of facility instrumentation and equipment for testing, calibration, and repairs.

\subsubsection{Identification}

Objective: Ensure that all test equipment that will be used as a standard for calibration and field checking equipment where a high degree of accuracy is required is properly identified. This includes the use of a unique identifier in the form of a master list containing the following: a generic description of the M\&TE, including the unique identifier, the accuracy range, the calibration procedure number, the calibration frequency, and the organization responsible for the M\&TE.

Discussion: All M\&TE is marked with a unique identifier. A master list of all M\&TE has been developed and is maintained by Westinghouse Hanford Standards Laboratory. The master list includes the following information: a generic description, the unique identifier, range and accuracy, calibration procedure and frequency, and the organization responsible for the M\&TE.

Improvement: Existing program practices satisfy intent of stated objective. Need for additional improvement or enhancement will be evaluated as part of ongoing self-assessment program.

\subsubsection{Calibration}

Objective: Calibration of M\&TE is accomplished by qualified personnel using approved procedures and standards having full traceability to the National Institute of Standards and Technology (NIST) or other nationally recognized standards. Standards used are maintained at designated controlled storage locations. 
Discussion: Calibration standards used to calibrate and adjust M\&TE are traceable to nationally recognized standards. Only trained and qualified technicians perform calibrations to approved procedures. Calibration frequencies are based on manufacturer's recommendations and historical performance.

Improvement: Existing maintenance program practices satisfy intent of stated objective. Need for additional improvement or enhancement will be evaluated as part of ongoing seifassessment program.

\subsubsection{Control}

Objective:

Ensure adequate control of M\&TE is maintained at all times. The program for controlling M\&TE must provide the following elements: controlled storage, proper calibration before use, identification of restrictions and limitations, recall of M\&TE from service before calibration is due. A log system ensures that M\&TE is traceable to the discrete pieces of equipment that it checked or calibrated, and that special protective measures are taken to ensure M\&TE does not become contaminated when used in a radioactive environment.

Discussion: All M\&TE is stored a manner that protects it from damage. All new M\&TE is calibrated before use. A system to recall M\&TE for calibration is in place and removes it from service before the calibration coming due. M\&TE is protected from radioactive and chemical contamination. A log system does exist that can be used to trace what equipment was checked or calibrated with a specific piece of M\&TE. However, this is a manual system and is extremely cumbersome. Improvements are required in this area. Users of M\&TE are made aware of restrictions and limitations at the time of issue.

Improvement: Develop and implement a logging system for M\&TE that ties each piece M\&TE to discreet pieces of equipment it was used to check or calibrate. This system must be simple to use and provide easy retrieval of the data, including the dates when the equipment was used.

\subsubsection{Evaluation}

Objective:

M\&TE usage is controlled and evaluated to ensure proper use, impact/consequence of out-of-tolerance equipment use, and equipment reliability.

Discussion: Use of M\&TE is controlled by procedures specifying equipment to be used (model, range) for given tasks. Performance information is retained to enable developing "use history" of M\&TE for evaluation when equipment is 
found (or suspected) of being out of tolerance. Calibration as-found conditions can be trended for equipment reliability evaluations.

Improvement: Existing maintenance program practices satisfy intent of stated objective. Need for additional improvement or enhancement will be evaluated as part of ongoing selfassessment program.

\subsection{MAINTENANCE TOOLS AND EQUIPMENT}

This section describes how Grout Facility Maintenance will establish methods to provide for storage, issuance, and maintenance of an adequate and readily available supply of tools and equipment and also for the development of special tools and equipment needed in the maintenance program.

Objective: Ensure that methods are established that provide for the storage and issuance of tools and equipment used to support maintenance activities. In addition, special maintenance requirements for special tools and equipment must be incorporated in the program. Procedures must be in place that describe how special tools and equipment are used/operated.

Discussion: Policies and procedures are in place that describe the requirements for storage, issuance, maintenance, and use of special tools and equipment. The Grout Facility currently does not have adequate storage for the issuance and control of tools and equipment. Tools and equipment are kept in a cabinet in the work area, connex boxes and desks. Due to inadequate storage and control, not all required tools and equipment have been purchased to date. Mobile Building M0-997 has been put in place and identified for use as a material storage building for tools and equipment as well as work package material laydown area. The condition of tools is monitored by the user and are repaired/replaced as deemed necessary.

Improvement: Complete the set-up of M0-997 and purchase the tools and equipment required to perform most maintenance work within our own facility. Mobile Building M0-997 will be the focal point for the issuance and control of tools and equipment.

\subsection{FACILITY CONDITION INSPECTION}

This section of the MIP describes how Grout Facility Management conducts periodic inspections of equipment and the facility to assure excellent facility condition and housekeeping.

Objective: Develop and implement a comprehensive program for the inspection and assessment of facility conditions. The 
program will be driven by specific standards, performed by personnel trained to perform facility condition inspections. In order to maintain discipline in the program, specific procedures for the conduct of the inspections, documentation of deficiencies and performance and follow-up required to correct deficiencies. Analys is will be performed of the data collected to determine if trends are present and develop actions to prevent recurrence.

Discussion: Currently, facility condition inspections are performed. While they are procedurally driven, they lack the depth to fully meet the requirements of DOE Order $4330.4 \mathrm{~A}$, Chapter 2.0. These inspections are not performed by persons who have specific training in facility inspection. Methods are in place for the documentation of deficiencies and initiating corrective actions.

Improvements: Identify standards and develop training for inspection personnel.

\subsection{MANAGEMENT INVO'LVEMENT}

This section of the MIP describes how management gets involved with facility operations, develops and monitors performance indicators, maintains open lines of communications horizontally and vertically, and reviews the effectiveness of the maintenance program.

\subsubsection{Manager Involvement}

This section describes how Grout managers become sufficiently involved with facility operations to be technically informed and personally familiar with Grout facility conditions.

Objectives: Upper-level managers will tour the facility on a routine, but unscheduled basis. First-line supervisors are expected to spend sufficient amounts of time in the field to monitor work in progress.

Discussion: First-line supervisors are expected to spend a percentage of their time monitoring work in the field. However, time has been limited due to the number of administrative duties a supervisor is expected to perform. Upper-level managers do not spend adequate time in the field monitoring work in progress. Expectations for supervisory and management involvement in field work must be communicated and tracked.

Improvement: The maintenance manager will document the expectations for managers and first-line supervisors to spend time in the field monitoring work in progress. These expectations 
should be documented as part of the Annual Performance Appraisal program.

Re-evaluate administrative duties of supervisors, reducing them where possible.

Elovate the priority of field visits for supervisors and maniger.

\subsubsection{Performance Indicators, Goais, and Objectives}

Objectives: Develop and maintain performance indicators that monitor trends and provide feedback on performance and progress towards stated goals and objectives. Implement a formal reporting system to disseminate information related to performance, goals and objectives.

Ciscussion: Performance indicators that monitor trends and provide feedback of performance and progress toward stated goals and objectives have been developed and are reviewed for applicability. The results of performance indicators are posted where all employees can review and-evaluate the results and corrective measures.

Improvemen:: Existing maintenance program practices satisfy intent of stated objective. Need for additional improvement or enhancement will be evaluated as part of ongoing selfassessment program.

\subsubsection{Feedback}

Objective: Maintain open lines of communication and feedback for the purpose of providing information related to facility activities. Craft persons have the opportunity to communicate their concerns, ideas, and observations to management through formal and informal means. Management communicate their interest, concerns, and observations to facility personnel.

Discussion: Communication and feedback systems currently exist for the purpose of providing information related to facility maintenance activities. Formal and informal channels of communication exist that provide opportunities for crafts and others to communicate their ideas, concerns, and observations to management. Management communicates their interest, concerns and expectations to facility personnel. Routinely, management conducts all employee meetings and roundtable sessions. The open door policy for management encourages parallel and upward communication. 
Improvement: Existing maintenance program practices satisfy intent of stated objective. Need for additional improvement or enhancement will be evaluated as part of ongoing selfassessment program.

\subsubsection{Program Reviews}

Objective: Develop an effective program to review the current status/condition of the maintenance program. Tools such as inspections, audits and self assessments should be used for this purpose. An assessment for compliance with DOE Order $4330.4 A$, Chapter 2.0, will be performed at least biannually. The program review should included, but is not limited to, facility condition and maintenance practices, maintenance training, procurement activities and practices, and M\&TE calibration and control.

Discussion: Internal and external inspections, audits, reviews and self-assessments are used to measure progress and the effectiveness of the maintenance program. Selfassessments of the maintenance program are planned at least every 2 years. Input for these assessments will be provided from other organizations such as Planning and Scheduling, Operations, as well as Maintenance. Program reviews will include ail 18 elements in DOE Order 4330.4A, Chapter 2.0.

Improvement: Conduct performance based self-assessments of maintenance program to identify programmatic deficiencies and initiate improvement plans.

\subsection{MAINTENANCE HISTORY}

This section describes how Grout Facility personnel will maintain a maintenance history and trending program to document data, provide historical information for maintenance planning, and support maintenance and performance trending of facility systems and components.

Objectives: Develop and implement a maintenance history program that provides historical data relevant to safety, critical process and high-value structures, systems, and components. The program provides data that can be used to -ipport maintenance planning and develop equipment performance trends. The program must be tied to facility master equipment and safety equipment 1 ist and must be automated for timely retrieval of data. The program shall include equipment identifications, data collections, identification of data collected, and conclusions related to equipment history.

Discussions: At present, there is no formal maintenance history program. The issuance of the MEL is essential for the 
development of a viable data base. The JCS database, CBRS Data Sheets or Procedure Job Cards are the only method available for maintenance history.

Improvement: Currently, a maintenance history module of the JCS is under development. Develop and implement a MEL.

\subsection{ANALYSis OF MAINTENANCE PROBLEMS}

This section describes how Grout Facility personnel will use systematic analysis to determine and correct root causes of unplanned occurrences related to maintenance.

Objective: To develop and implement a program for the systematic analysis of maintenance problems that result in unplanned occurrences. This program should include information collection, event analysis, cause determination, corrective action followup and generic followup.

Discussion: Currently there is no program for the systematic analysis of maintenance problems that result in unplanned occurrences. Analysis of maintenance problems is an essential part of prevention. Maintenance history is a critical element of this process along with historical data acquired through event report process. Actions are taken based on lessons learned and through formal reviews of event reports to categorize problem areas and develop actions to prevent recurrence. The Priority Planning Grid concept is used to establish the level of importance to events and level of analys is required.

Improvement: Continue to review problems identified through lessons learned and through the event reporting system. Develop data related to trends or significant individual occurrences. Make revisions to PM or other procedures to prevent recurrence. Make additional improvement when the Maintenance history program has been put in place.

\subsection{MODIFICATION WORK}

This section describes how Grout Facility personnel will account for modification work. This should be accomplished under the same basic administrative controls as those applied to facility maintenance activities so that there is no increase in risk to facility equipment environment or personnel because of modification work.

Objective: Maintenance personnel should be cognizant of the effects of modification work before modification of structures, systems, and components. This awareness is required in order to identify any effects on existing programs such as procedure development and preventive or predictive maintenance. Procedures need to be in place to assure 
that temporary modifications receive an adequate safety review. Temporary modifications and repairs are tracked until they become permanent.

Discussion: Currently, processes exist that provide Maintenance the opportunity to evaluate the effects of modifications. Procedures, training, and preventive maintenance changes are considered. Temporary modifications and repairs do receive appropriate safety review. Temporary modifications and repairs are tracked through the Job Control System until permanent repairs or modifications are complete.

Improvement: Existing maintenance program practices satisfy intent of stated objective. Need for additional improvement or enhancement will be evaluated as part of ongoing selfassessment program.

\subsection{SEASONAL FACILITY PRESERVATION REQUIREMENTS}

This section describes the actions taken by Grout Facility personnel to ensure that structures, systems, and components are adequately protected from the effects of freezing conditions.

\subsubsection{Cold Weather/Freeze Protection Plan}

Objective: Develop a plan of action that will adequately protect facility structures, systems, componenis from the detrimental effects that result from freezing conditions and equipment.

Discussion: Sitewide policies and site-specific procedures are in place that describe the responsibility of the facility operator to identify these structures, systems, and components that will or have the potential of being damaged as the result of freezing. They al so describe the maintenance responsibility to take the appropriate action to prevent freeze-ups.

Improvement: Existing maintenance program practices satisfy intent of stated objective. Need for additional improvement or enhancement will be evaluated as part of ongoing selfassessment program.

\subsubsection{Actions Required}

Objective: Address adequately the actions required by Operations and Maintenance to prevent damage from freeze-ups. 
Discussion: Existing sitewide procedure describe the actions that must be taken by Operations and Maintenance to prevent freezeups. These procedures address when the plan must be implemented to prevent to premature freeze-ups and additional requirements that need to be put in place when weather gets colder than normal for this geographic location.

Improvement: Existing maintenance program practices satisfy intent of stated objective. Need for additional improvement or enhancement will be evaluated as part of ongoing selfassessment program.

\subsubsection{Surveillance}

Objective: The operations surveillance and the preventive maintenance program will ensure that systems protected from freeze-up are routinely checked to see that protective systems are operating properly and to identify areas may require additional protection.

Discussion: Current procedures require routine surveillance of areas that could be effected by freezing weather. Surveillance requirements include assuring that if additional freeze protection is required and increasing surveillance frequencies when colder than normal weather is experience. Operations and Maintenance surveillance activities ensure compliance and measure the effectiveness of actions taken to prevent facility freeze-up.

Improvement: Existing maintenance program practices satisfy intent of stated objective. Need for additional improvement or enhancement will be evaluated as part of ongoing selfassessment program. 
WHC-SP-0918, Rev. 0

This page intentionally left blank. 
WHC-SP-0918, Rev. 0

\subsection{DEVIATIONS}

There are no deviations requested. 
WHC-SP-0918, Rev. 0

This page intentionally left blank. 
WHC-SP-0918, Rev. 0

\subsection{IMPLEMENTATION SCHEDULE}

The following schedule (Table 1) is provided to present a general overview of work activities required for compliance with DOE Order 4330.4A, using a graded approach, and the projected timeframes for accomplishment. However, note that this plan provides a specific commitment for initiation and completion of those activities designated as Phase 1 and Phase 2; Phase 3 projections are provided for reference and planning purposes only. 
Table 1. 4330.4A Maintenance Implementation Plan Schedule.

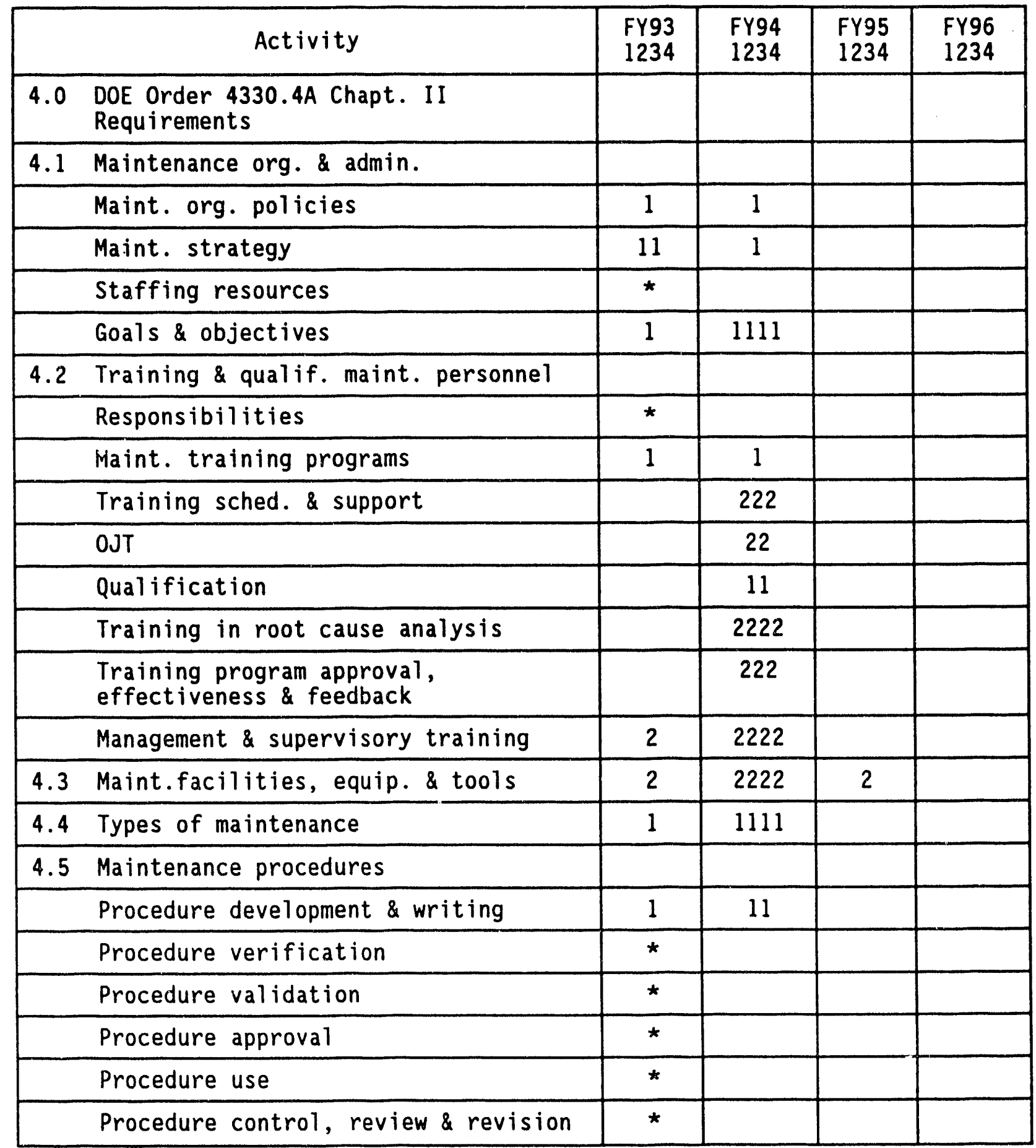


Table 1. 4330.4A Maintenance Implementation Plan Schedule.

\begin{tabular}{|c|c|c|c|c|}
\hline Activity & $\begin{array}{l}\text { FY93 } \\
1234\end{array}$ & $\begin{array}{l}\text { FY94 } \\
1234\end{array}$ & $\begin{array}{l}\text { FY95 } \\
1234\end{array}$ & $\begin{array}{l}\text { FY96 } \\
1234\end{array}$ \\
\hline $\begin{array}{l}\text { 4.6 Planning, scheduling \& coord. of } \\
\text { maintenance }\end{array}$ & & & & \\
\hline Planning for maint. activities & * & & & \\
\hline Scheduling maint. activities & 1 & 1 & & \\
\hline Coordination of maint. activities & 1 & & & \\
\hline Outage planning, scheduling \& coord. & & 11 & & \\
\hline 4.7 Control of maintenance activities & & & & \\
\hline Work control procedure & * & & & \\
\hline Work request & * & & & \\
\hline Supervisor of maint. activities & & 2 & & \\
\hline Review of completed work requests & * & & & \\
\hline Temporary repairs & * & & & \\
\hline $\begin{array}{l}\text { Control of nonnuclear fac. contractor } \\
\text { \& subcontractor personnel }\end{array}$ & * & & & \\
\hline 4.8 Postmaintenance testing & * & & & \\
\hline Postmaintenance test requirements & * & & & \\
\hline Postmaintenance test scope & * & & & \\
\hline Postmaintenance test control & * & & & \\
\hline $\begin{array}{l}\text { Postmaintenance test performance, } \\
\text { documentation, \& acceptance }\end{array}$ & * & & & \\
\hline $\begin{array}{l}4.9 \text { Procurement of parts, materials, \& } \\
\text { services }\end{array}$ & * & & & \\
\hline $\begin{array}{l}\text { 4.10 Material receipt, inspec., handling, } \\
\text { storage retrieval \& issuance }\end{array}$ & & & & \\
\hline Receipt Inspection & * & & & \\
\hline Handl ing & * & & & \\
\hline Storage Material \& Equipment & 2 & 22 & & \\
\hline Retrieval and Issuance & * & & & \\
\hline
\end{tabular}


Table 1. 4330.4A Maintenance Implementation Plan Schedule.

\begin{tabular}{|l|c|c|c|c|}
\hline \multicolumn{1}{|c|}{ Activity } & $\begin{array}{c}\text { FY93 } \\
1234\end{array}$ & $\begin{array}{c}\text { FY94 } \\
1234\end{array}$ & $\begin{array}{c}\text { FY95 } \\
1234\end{array}$ & $\begin{array}{c}\text { FY96 } \\
1234\end{array}$ \\
\hline $\begin{array}{l}\text { 4.11 } \begin{array}{l}\text { Control \& calibration of measuring \& } \\
\text { test equipment }\end{array} \\
\text { Identification }\end{array}$ & & & \\
\hline Calibration & $\star$ & & & \\
\hline Control & & 2 & 2 & \\
\hline Evaluation & $*$ & & & \\
\hline 4.12 Maintenance tools \& equipment & 2 & 2 & & \\
\hline 4.13 Facility condition inspection & & 33 & & \\
\hline 4.14 Management involvement & $\star$ & & & \\
\hline Manager involvement & 3 & & & \\
\hline $\begin{array}{l}\text { Performance indicators, goals \& } \\
\text { objectives }\end{array}$ & $\star$ & & & \\
\hline Feedback & $\star$ & & & \\
\hline Program reviews & 33 & 3 & & \\
\hline 4.15 Maintenance history & 2 & 22 & & \\
\hline 4.16 Analysis of maintenance problems & & 2222 & & \\
\hline 4.17 Modification work & $\star$ & & & \\
\hline 4.18 Seasonal facility preservation \\
requirements
\end{tabular}

NOTE: $\quad$ 1. Number represents Phase $(1,2,3)$ in which activity is to be addressed and placement indicates fiscal year quarter in which the work is scheduled.

2. An asterisk (*) indicates that no activity is scheduled for this item. 


\subsection{REFERENCES}

DOE, 1990, Maintenance Management Program, DOE Order 4330.4A, U.S. Department of Energy, Wasnington, D.C.

DOE, 1984, Safety of Nuclear Facilities, DOE Order 5480.5, U.S. Department of Energy, Washington, D.C.

DOE, 1987, Final Environmental Impact Statement Disposal of Hanford Defense High-Level, Transuranic and Tank Wastes, DOE/EIS-0113, Vol. 1-5,

U.S. Department of Energy, Washington, D.C.

DOE, 1986, Safety of Department of Energy - Owned Nuclear Reactors, DOE Order 5480.6, U.S. Department of Energy, Washington, D.C.

DOE, 1991a, Personnel, Selection, Qualification, Training, and Staffing Requirements at DOE Reactor and Non-Reactor Facilities, DOE Order 5480.20 , U.S. Department of Energy, Washington, D.C.

DOE, 1991b, Quality Assurance, DOE Order 5700.6C, U.S. Department of Energy, Washington, D.C.

Ecology, EPA, and DOE, 1992, Hanford Federal Facility Agreement and Consent Order, 2 vols., Washington State Department of Ecology, U.S. Environmental Protection Agency, and U.S. Department of Energy, Olympia, Washington.

WHC, 1992, Grout Treatment Facility Final Safety Analysis Report, WHC-SD-WM-SAR-042, Rev. OA, Westinghouse Hanford Company, Richland, Washington. 
WHC-SP-0918, Rev. 0

This page intentionally left blank.

$7-2$ 
WHC-SP-0918, Rev. 0

\section{DISTRIBUTION}

\section{Number of Copies}

\section{ONSITE}

3

U.S. Department of Energy

Richland Field office

R. Carreon

R3-74

J. V. Prather

R3-82

G. H. Sanders

R3-74

16

\section{Westinghouse Hanford Company}

W. T. Alumkal

R2-52

H. D. Harmon

R2-52

D. C. Hussey

S4-43

B. G. Lauzon

R. J. Murkowski

R1-08

D. R. Nunamaker

R4-02

M. A. Payne

S4-43

S. H. Rifaey

R2-50

J. L. Vigue'

S6-12

A. K. Yoakum

$S 4-43$

Central Files

$54-43$

Information Release Administration (3)

Document Processing and Distribution (2)

L8-04

R1-08

L8- 15 
WHC-SP-0918, Rev. 0

This page intentionally left blank.

Distr-2 

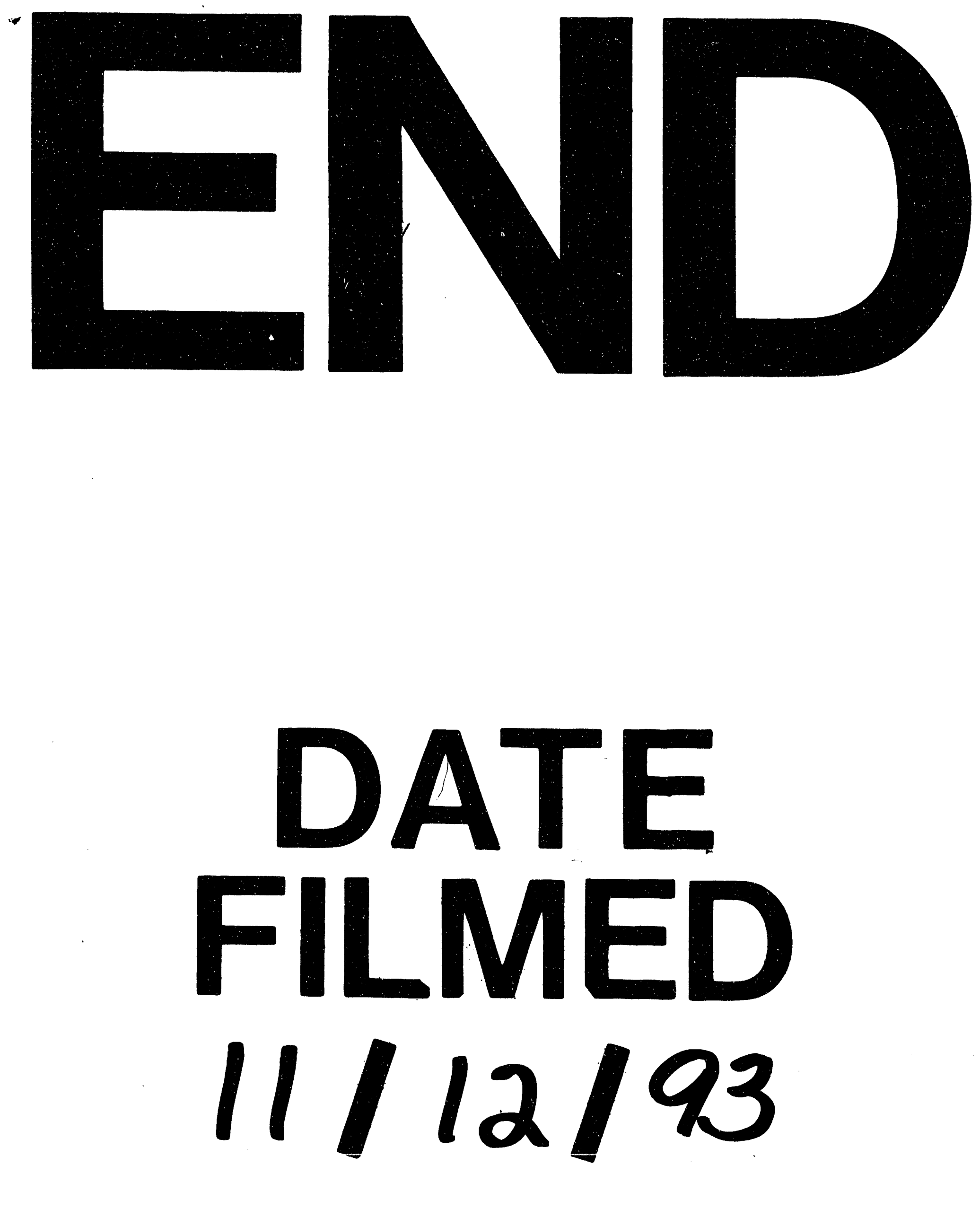

1 
